\title{
Lysine-Specific Demethylase 3A
}

National Cancer Institute

\section{Source}

National Cancer Institute. Lysine-Specific Demethylase 3A. NCI Thesaurus. Code C134313.

Lysine-specific demethylase 3A (1321 aa, 147 kDa) is encoded by the human KDM3A gene. This protein is involved in the demethylation of lysine-9 of histone H3 (H3K9). 